\title{
Assessment of genetic relationship among Rhododendron cultivars using amplified fragment length polymorphism and inter- simple sequence repeat markers
}

\author{
J.J. Xu, B. Zhao, H.F. Shen, W.M. Huang and L.X. Yuan \\ College of Landscape Architecture and Arts, Northwest A\&F University, \\ Yangling, China \\ Corresponding author: B. Zhao \\ E-mail: bingbing2003915@163.com
}

Genet. Mol. Res. 15 (3): gmr.15038467

Received January 20, 2016

Accepted March 11, 2016

Published August 18, 2016

DOI http://dx.doi.org/10.4238/gmr.15038467

Copyright (C) 2016 The Authors. This is an open-access article distributed under the terms of the Creative Commons Attribution ShareAlike (CC BY-SA) 4.0 License.

\begin{abstract}
Genetic relationships of 17 Rhododendron cultivars, China, were assessed using inter-simple sequence repeat (ISSR) and amplified fragment length polymorphism (AFLP) markers. A total of 133 bands were obtained using nine selected ISSR primers, 129 (96.99\%) of which were polymorphic; 267 bands were amplified by four AFLP primer pairs, 251 (94.01\%) of which exhibited polymorphism. Based on these polymorphic products, a cluster analysis revealed similarities between the results of the ISSR and AFLP. All of the cultivars were clustered into two major branches; one branch contained the same four cultivars, and the other cultivars were separated into different groups in the other branch. The cluster results showed that the genetic relationships of the 17 cultivars were partly related to their morphological characteristics, particularly the flowering
\end{abstract}


phase. Therefore, the results of this study support the classification of Rhododendron cultivars according to flowering phase. In addition, the cluster results can be used to select suitable parents for breeding.

Key words: Rhododendron; Genetic relationship; AFLP; ISSR; Morphological characteristic; Cluster analysis

\section{INTRODUCTION}

Many species of Rhododendron are native to Asia, and were introduced to Europe to create new cultivars in the 18th century (Zhou et al., 2013). In China, they are used as indoor ornamental plants because of their flower types, brilliant colors, and other ornamental features, and are classified into three different groups according to their flowering phase (Chen, 2001): spring azaleas, summer azaleas, and spring and summer azaleas. However, other classification systems exist, including classification into four groups based on their phenotypes and origins (Huang and Qiang, 1984).

Molecular markers are powerful tools for estimating genetic diversity and distinguishing between different individuals that have different origins or morphologies (Peng et al., 2014). Several polymerase chain reaction (PCR)-based markers have been used to investigate genetic diversity and relationships, such as random amplified polymorphic DNA (Wang et al., 2012), sequence-related amplified polymorphism (Mokhtari et al., 2013), simple sequence repeats (Souza et al., 2009; Liu et al., 2012), inter-simple sequence repeats (ISSRs) (Al-Turki and Basahi, 2015; Zhan et al., 2015), and amplified fragment length polymorphism (AFLP) (Elameen et al., 2008; Larsen et al., 2015). The ISSR technique amplifies DNA fragments that are located between two identical microsatellites, and is a simple and efficient technique to estimate genetic relationships; AFLP is the best choice for analyzing population genetic and genetic relationships when there is little genetic information available (Zhao et al., 2012).

The assessment of genetic relationships is important for breeding and cultivar classification. There are a large number of Rhododendron resources, including wild resources and cultivars. The genetic relationships and diversity of wild Rhododendron plants have been estimated in previous studies (Liu et al., 2012; Zhao et al., 2015), but few studies have investigated genetic relationships among Rhododendron cultivars. In the present study, we investigated the genetic relationships among 17 Rhododendron cultivars using ISSR and AFLP markers, and compared their morphological characteristics. Characterizing cultivars using molecular tools can accurately elucidate genetic relationships, in order to identify the correct taxonomic status of varieties and contribute to possible breeding programs (ValadezMoctezuma et al., 2015).

\section{MATERIAL AND METHODS}

\section{Plant materials and morphological characterization}

The 17 Rhododendron cultivars that were used belonged to three groups: 14 were spring azaleas, two were summer azaleas, and one was a spring and summer azalea (Table 1). Ten individuals of each cultivar were used. All of the samples (fresh leaves taken from annual shoots) were collected from Jiashan, China, and planted in a greenhouse at Yangling, China.

Genetics and Molecular Research 15 (3): gmr.15038467 
Table 1. Samples and their morphological characteristics.

\begin{tabular}{l|l|l|l|c|l|c|c|c}
\hline No. & Name & Group & Flowering phase & $\begin{array}{l}\text { Floret } \\
\text { number }\end{array}$ & $\begin{array}{l}\text { Flower } \\
\text { color }\end{array}$ & $\begin{array}{c}\text { Leaf } \\
\text { length } \\
(\mathrm{cm})\end{array}$ & $\begin{array}{c}\text { Leaf width } \\
(\mathrm{cm})\end{array}$ & $\begin{array}{c}\text { Stipe length } \\
(\mathrm{cm})\end{array}$ \\
\hline 1 & R. 'Xiao Qing Lian' & spring azalea & End of March & $2-5$ & violet & 2.7 & 1.4 & 0.259 \\
\hline 2 & R. 'Bi Zhi' & spring azalea & Mid-March & $3-4$ & violet & 1.8 & 1 & 0.3 \\
\hline 3 & R. 'WaiGuo Hong' & spring azalea & End of March & $2-3$ & pink & 2.5 & 1.3 & 0.27 \\
\hline 4 & R. 'Tao Ban Zhu Sha' & spring azalea & End of March & 3 & cinnabar & 1.7 & 0.9 & 0.29 \\
\hline 5 & R. 'Lv Se GuangHui' & summer azalea & End of April & $2-5$ & green & 3 & 1.8 & 0.27 \\
\hline 6 & R. 'Yu Ling Long' & spring azalea & End of April & $3-4$ & pink white & 2.7 & 1.5 & 1.22 \\
\hline 7 & R. 'Song Jiang Da Tao Hong' & spring azalea & End of April & $2-3$ & pink & 2.6 & 1.1 & 0.25 \\
\hline 8 & R. 'Ning Bo Hong' & spring azalea & End of April & $3-4$ & red & 2.1 & 1 & 0.23 \\
\hline 9 & R. 'Xiao Tao Hong' & spring azalea & Early April & $2-5$ & pink & 2 & 1 & 0.3 \\
\hline 10 & R. 'Hong Yue' & spring azalea & Early April & $2-4$ & pink & 3.3 & 1.5 & 0.24 \\
\hline 11 & R. 'HuoFeng Huang' & spring azalea & End of March & 2 & red & 3.3 & 2 & 0.4 \\
\hline 12 & R. 'Ai Ding Bao' & spring azalea & End of April & $3-4$ & violet & 3.2 & 1.3 & 0.33 \\
\hline 13 & R. 'Zi Chen Dian' & summer azalea & May to June & $2-3$ & violet & 2.2 & 1.2 & 0.33 \\
\hline 14 & R. 'Hong Shan Hong' & spring and & End of April & $2-3$ & red & 1.8 & 1 & 0.23 \\
\hline 15 & R. 'Zhuang Yuan Hong' & summer azalea & & & & & 1 \\
\hline 16 & R. 'Lan Ying' & spring azalea & End of March & $2-4$ & pink & 2.1 & 1 & 0.19 \\
\hline 17 & R. 'TuRui Mei Gui' & spring azalea & Early April & $2-3$ & violet & 2.8 & 1.7 & 1.17 \\
\hline
\end{tabular}

A morphological characterization of the flowers was conducted in the greenhouse during the full-bloom stage, and mature leaves were used to record leaf characteristics. Six characteristics were investigated: flowering phase, flower color, floret number, leaf length, leaf width, and the ratio of petiole length and leaf length. A detailed description of the samples and the morphological characterization is provided in Table 1.

\section{DNA extraction}

Total genomic DNA was extracted from approximately $100 \mathrm{mg}$ leaf tissue suspended in double distilled $\mathrm{H}_{2} \mathrm{O}\left(\mathrm{ddH}_{2} \mathrm{O}\right)$ using a Plant Genomic DNA Kit (Tiangen, Beijing, China). The quantity and quality of the extracted DNA was evaluated by ultraviolet spectrophotometry (Thermo Fisher NanoDrop, USA) and determined on 1\% agarose gels and 1X TAE buffer [40 $\mathrm{mM}$ Tris-acetate and $1 \mathrm{mM}$ ethylenediaminetetraacetic acid (EDTA), $\mathrm{pH}$ 8.0]. The DNA was stored at $-20^{\circ} \mathrm{C}$ until use.

\section{ISSR analysis}

Forty primers were evaluated for DNA amplification, which were synthesized according to the sequence obtained from the University of British Columbia, Canada; nine were selected to amplify informative fingerprints (Table 2). The PCR mixture contained 2.5 $\mu \mathrm{L}$ DNA (50 ng/ $\mu \mathrm{L}$ ), $10 \mu \mathrm{L} \mathrm{ddH_{2 }} \mathrm{O}$, and $12.5 \mu \mathrm{L}$ primer mix (TaKaRa Taq ${ }^{\mathrm{TM}}$ Version 2.0). Amplifications were conducted as follows: $10 \mathrm{~min}$ of denaturation at $94^{\circ} \mathrm{C} ; 35$ cycles with three steps: $45 \mathrm{~s}$ of denaturation at $94^{\circ} \mathrm{C}, 45 \mathrm{~s}$ of annealing at $55^{\circ} \mathrm{C}$, and $90 \mathrm{~s}$ of elongation at $72^{\circ} \mathrm{C}$; and a final elongation at $72^{\circ} \mathrm{C}$ for $8 \mathrm{~min}$. The amplification products were determined on $2 \%$ agarose gels using a 2000-bp DNA Ladder, with $1 \mathrm{X}$ TAE buffer for $40 \mathrm{~min}$ at $120 \mathrm{~V}$. The gels were visualized by ethidium bromide staining and were then photographed. The ISSR was conducted twice. 


\section{AFLP analysis}

AFLP analysis was performed according to Vos et al. (1995), with minor modifications. Firstly, $5 \mu \mathrm{L}$ genomic DNA from each sample was digested with $5 \mathrm{U} M s e \mathrm{I}$ and $5 \mathrm{U}$ EcoRI, and then the restricted DNA fragments were ligated to EcoRI and $M s e I$ adapters. The digestion and connection was conducted at $37^{\circ} \mathrm{C}$ for $4 \mathrm{~h}$, and the products were diluted 10 -fold with $\mathrm{ddH}_{2} \mathrm{O}$ for pre-amplification.

The pre-amplified reaction mixture contained $4.4 \mu \mathrm{L} \mathrm{ddH}_{2} \mathrm{O}, 0.6 \mu \mathrm{L}$ primers based on the EcoRI and MseI adapter sequences, $10 \mu \mathrm{L}$ premix Taq (TaKaRa), and $5 \mu \mathrm{L}$ DNA fragments. The PCR was performed with the following profile: 2 min at $94^{\circ} \mathrm{C} ; 30 \mathrm{~s}$ at $94^{\circ} \mathrm{C}$, $30 \mathrm{~s}$ at $56^{\circ} \mathrm{C}, 1 \mathrm{~min}$ at $72^{\circ} \mathrm{C}$ for $24 \mathrm{cycles}$; and $10 \mathrm{~min}$ at $72^{\circ} \mathrm{C}$. The products were diluted $10-$ fold with $\mathrm{ddH}_{2} \mathrm{O}$ for selective amplification.

Initially, 64 primer pairs were tested for amplification of the pre-amplified DNA; four were used to amplify the samples (Table 2) with the following profile: 4 min at $94^{\circ} \mathrm{C}, 12$ cycles of $30 \mathrm{~s}$ at $94^{\circ} \mathrm{C}, 30 \mathrm{~s}$ at $65^{\circ} \mathrm{C}$ (decreasing the temperature by $0.7^{\circ} \mathrm{C}$ over each cycle), $1 \mathrm{~min}$ at $72^{\circ} \mathrm{C}, 26$ cycles of denaturation at $94^{\circ} \mathrm{C}$ for $30 \mathrm{~s}$, annealing at $56^{\circ} \mathrm{C}$ for $30 \mathrm{~s}$, an extension at $72^{\circ} \mathrm{C}$ for $1 \mathrm{~min}$, and a final extension at $72^{\circ} \mathrm{C}$ for $8 \mathrm{~min}$.

For the analysis, the selective amplification products were mixed with $7 \mu \mathrm{L}$ denaturation buffer, denatured at $98^{\circ} \mathrm{C}$ for $8 \mathrm{~min}$, and cooled in ice. The products were separated by $6 \%$ polyacrylamide gel electrophores in $1 \mathrm{X}$ TBE buffer $(89 \mathrm{mM}$ Tris-borate and $2 \mathrm{mM}$ EDTA, $\mathrm{pH}$ 8.0) for $90 \mathrm{~min}$ at $65 \mathrm{~W}$, and stained with silver-staining solution. In order to prevent experimental error and ensure the reliability of the results, pre-amplification, selective amplification, and gel electrophoresis were conducted twice.

\section{Data analysis}

The amplified fragments were manually scored as 1 for present and 0 for absent for all of the ISSR unambiguous fragments (Figure 1) and distinct bands of the AFLP fragments (60-600 bp) (Figure 2). Two matrices were then created, which were used in further analysis. Dendrograms were constructed in order to determine relationships among the 17 cultivars by the unweighted pair group method with arithmetic mean based on Nei's unbiased genetic distance matrix, using NTSYSpc ver. 2.10.

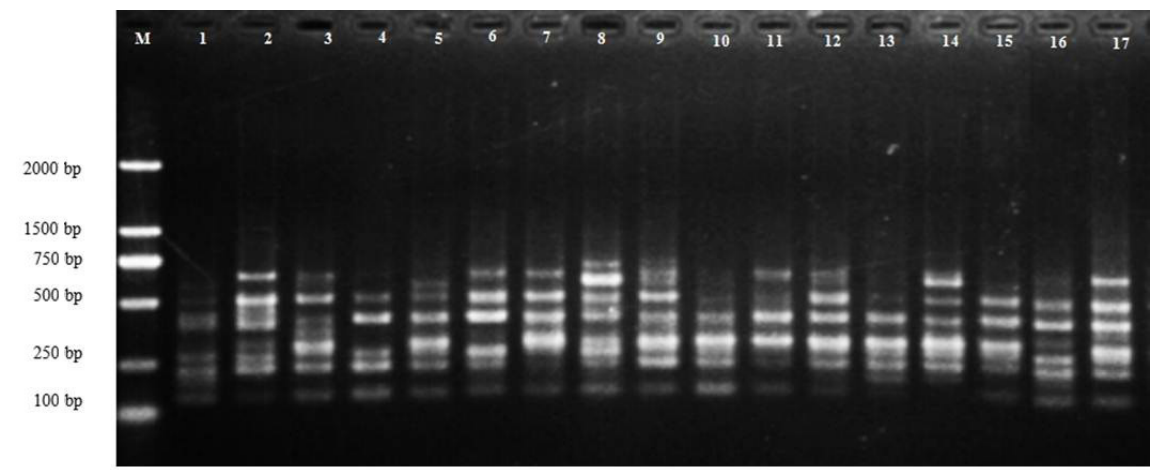

Figure 1. Inter-simple sequence repeat fingerprinting patterns of samples using the primer UBC841. Lane $M=$ molecular marker; lanes $1-17=$ Rhododendron cultivars.

Genetics and Molecular Research 15 (3): gmr.15038467 


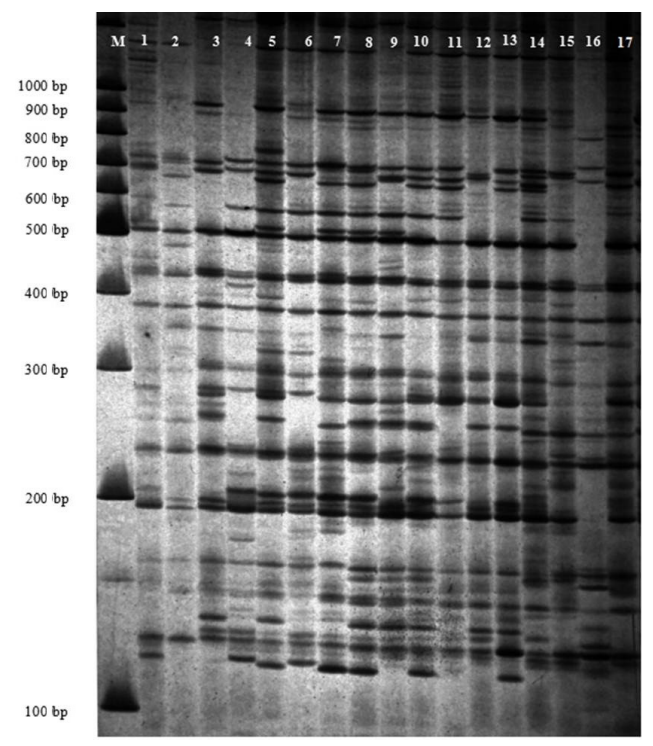

Figure 2. Amplified fragment length polymorphism fingerprinting patterns of samples using the primer combination M-CAT/E-ACC. Lane $M=$ molecular marker; lanes 1-17= Rhododendron cultivars.

\section{RESULTS}

\section{Primer selection and polymorphism of amplified bands}

In the ISSR analysis, the 17 Rhododendron cultivars were assessed using nine ISSR primers (Table 2), which generated different numbers and sizes of polymorphic fragments (Figure 1). A total of 133 bands were amplified that ranged between 100 and $1700 \mathrm{bp}$ long; 129 were polymorphic with a minimum of 12 bands (UBC811), a maximum of 17 bands (UBC816, UBC817, and UBC841), and an average of 14.78 bands per primer. The percentage of polymorphic bands ranged from 92.86 (UBC819) to 100\% (UBC811, UBC818, UBC823, $\mathrm{UBC} 830$, and $\mathrm{UBC} 842$ ).

Table 2. Polymorphisms obtained by inter-simple sequence repeat (ISSR) and amplified fragment length polymorphism (AFLP) markers.

\begin{tabular}{|c|c|c|c|c|c|c|c|}
\hline \multicolumn{4}{|c|}{ ISSR } & \multicolumn{4}{|c|}{ AFLP } \\
\hline Primer & Bands generated & $\mathrm{N}$ & PPB (\%) & Primer combination & Bands generated & $\mathrm{N}$ & PPB (\%) \\
\hline UBC811 & 12 & 12 & 100.00 & M-CTG/E-ACT & 49 & 48 & 97.96 \\
\hline UBC816 & 17 & 16 & 94.12 & M-CTG/E-ACC & 58 & 52 & 89.66 \\
\hline UBC817 & 17 & 16 & 94.12 & M-CAT/E-ACC & 88 & 84 & 95.45 \\
\hline UBC818 & 15 & 15 & 100.00 & M-CAT/E-ACG & 72 & 67 & 93.06 \\
\hline UBC819 & 14 & 13 & 92.86 & Total & 267 & 251 & \\
\hline UBC823 & 14 & 14 & 100.00 & Average & 66.75 & 62.75 & 94.01 \\
\hline UBC830 & 13 & 13 & 100.00 & & & & \\
\hline UBC841 & 17 & 16 & 94.12 & & & & \\
\hline UBC842 & 14 & 14 & 100.00 & & & & \\
\hline Total & 133 & 129 & & & & & \\
\hline Average & 14.78 & 14.33 & 96.99 & & & & \\
\hline
\end{tabular}

$\mathrm{PPB}$, percentage of polymorphic bands. 
In the AFLP analysis, the samples were evaluated using four primer pairs (Table 2), which amplified 267 bands; 251 of them were polymorphic, with a maximum of 88 bands (M-CAT/EACC). The bands ranged between 60 and $600 \mathrm{bp}$ long, and the percentage of polymorphic bands per primer pair varied from 89.66 (M-CTG/E-ACC) to $97.96 \%$ (M-CTG/E-ACT).

\section{Genetic relationship analysis}

Genetic relationship parameters of the 17 cultivars were compared using the molecular marker and cluster analysis results. Using ISSR markers, the genetic coefficient was between 0.56 and 0.82, the maximum was between 'Ning Bo Hong' and 'Yu Ling Long', and the minimum was between 'Lv Se Guang Hui', 'Zhuang Yuan Hong', and 'Tu Rui Mei Gui'. The cultivars were clustered into two groups (Figure 3) when setting the threshold value at 0.63 ; four were clustered in Group II ('Hong Shan Hong', 'Zhuang Yuan Hong', 'Tu Rui Mei Gui', and 'Lan Ying') and the rest were clustered in Group I. The flowering phases of the cultivars in Group II were earlier than those of the others, and their leaves were wider than those in Group I.

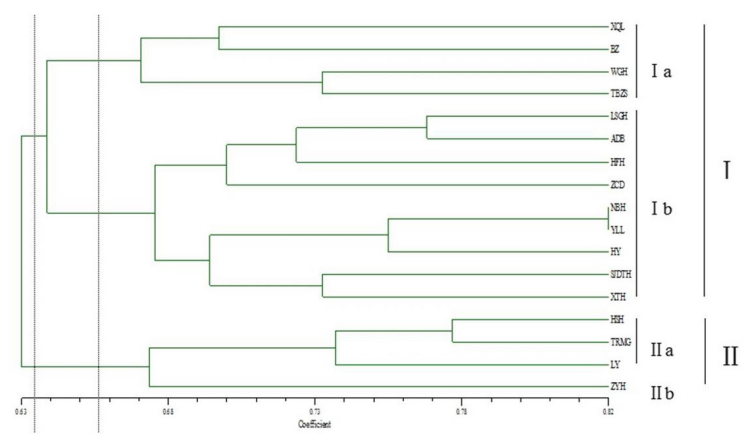

Figure 3. Dendrogram of polymorphic DNA of 17 Rhododendron genotypes by inter-simple sequence repeat cluster analysis.

Using AFLP markers, the genetic coefficient varied from 0.57 to 0.85 , the maximum was between 'Ning Bo Hong' and 'Yu Ling Long', and the minimum was between 'Ai Ding Bao' and 'Tu Rui Mei Gui'. The AFLP-based dendrogram had two major branches (Figure 4) with the threshold value set at 0.66 . One branch contained the same four cultivars as Group II by ISSR, and the other cultivars shared the other branch.

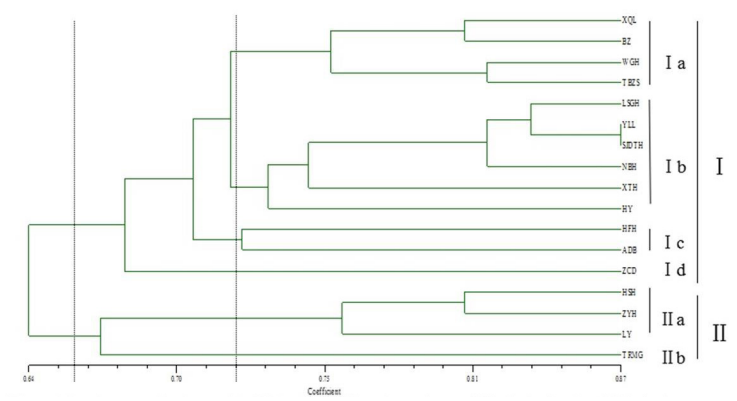

Figure 4. Dendrogram of polymorphic DNA of 17 Rhododendron genotypes by amplified fragment length polymorphism cluster analysis.

Genetics and Molecular Research 15 (3): gmr.15038467 


\section{DISCUSSION}

Recently, ISSR and AFLP techniques have been used in studies of genetic diversity (Kumar et al., 2015; Zhang et al., 2015), plant classification, and genetic relationships (Miyashita et al., 2015), including in the Rhododendron. Scariot et al. (2007a,b) classified evergreen azalea cultivars using AFLP markers, and compared the capacity and effectiveness of AFLP, sequence-tagged microsatellite site, and expressed sequence tag markers in assessing genetic relationships among evergreen azaleas. The authors found that AFLP could be used in assessing genetic relationships among Rhododendron varieties. Morphological characterization is the first step in discovering new resources, and is the most direct method of classifying plants and determining their genetic relationships, e.g., Chrysanthemum cultivars (Guan et al., 2013) and pea (Jha et al., 2013). In the present study, six morphological characteristics were selected to cluster samples in order to compare AFLP and ISSR.

The average percentage of polymorphic bands detected by ISSR primers was $96.99 \%$, and by AFLP, it was $94.01 \%$. Liu et al. (2012) reported $87.43 \%$ polymorphism in $R$. aureum at four different altitudes using ISSR, and Zhao et al. (2012) found $92.04 \%$ polymorphism in five species of Rhododendron using AFLP.

The clustering patterns that were obtained by ISSR and AFLP had a certain similarity. The cultivars were clustered into two groups by both ISSR and AFLP, with four in Group II and the remainder in Group I. The difference between the two results was that four cultivars were clustered into two different groups in Group II. The ISSR clustered 'Tu Rui Mei Gui' into Group IIb; however, the AFLP clustered it into Group IIa, and 'Zhuang Yuan Hong' into Group IIb. The flowering phases of the cultivars in Group II were earlier than those of the other cultivars, and their leaves were wider than those in Group I. There were two groups (Ia and $\mathrm{Ib}$ ) in Group I according to the ISSR (with a coefficient value of 0.64), and four groups (Ia, Ib, Ic, and Id) according to the AFLP (with a coefficient value of 0.72 ).

The cultivars in ISSR Group Ia were the same as those in AFLP Group Ia, and the flowering phases of the species in Group Ia were earlier than those of the others. These four species were clearly separated into two branches, consistent with their flower colors: one branch contained 'Xiao Qing Lian' and 'Bi Zhi', and the other contained 'Wai Guo Hong' and 'Tao Ban Zhu Sha'. In ISSR Group Ib, one branch contained the cultivars 'Lv Se Guang Hui', 'Ai Ding Bao', 'Huo Feng Huang', and 'Zi Chen Dian', and the flowering phases of these cultivars were later and their leaves longer than those of the others; the other branch contained five cultivars. In the AFLP analysis, nine cultivars were separated into four branches, and six of them shared the same branch: 'Lv Se Guang Hui', 'Yu Ling Long', 'Song Jiang Da Tao Hong', 'Ning Bo Hong', 'Xiao Tao Hong', and 'Hong Yue'. 'Huo Feng Huang' and 'Ai Ding Bao' were in Group Ic and 'Zi Chen Dian' was alone in Group Id. The classification of the nine cultivars corresponded to their flowering phases.

Several previous studies that used morphological characteristics and molecular markers have reported a lack of consistency between them (Pham et al., 2011; Peng et al., 2014). This study demonstrated that the clustering results obtained by AFLP and ISSR are generally related to morphological characterization, particularly of the flowering phase. Therefore, our results support the classification of Rhododendron cultivars based on their flowering phases. In addition, the cluster results revealed the genetic relationships among the 17 Rhododendron cultivars studied, which can be used to select suitable parents for breeding.

Genetics and Molecular Research 15 (3): gmr.15038467 


\section{ACKNOWLEDGMENTS}

Research supported by the International Science and Technology Cooperation Foundation (\#A213021501) and the National Natural Science Foundation (\#K305021401).

\section{REFERENCES}

Al-Turki TA and Basahi MA (2015). Assessment of ISSR based molecular genetic diversity of Hassawi rice in Saudi Arabia. Saudi J. Biol. Sci. 22: 591-599. http://dx.doi.org/10.1016/j.sjbs.2015.06.027

Chen JY (2001). Chinese flower species taxonomy. China Forestry Publishing House.

Elameen A, Klemsdal SS, Dragland S, Fjellheim S, et al. (2008). Genetic diversity in a germplasm collection of rose root (Rhodiola rosea) in Norway studied by AFLP. Biochem. Syst. Ecol. 9: 706-715. http://dx.doi.org/10.1016/j. bse.2008.07.009

Guan ZY, Wang JM, Chen FD, Fang WM, et al. (2013). Phylogenetic research based on morphological characters from DUS test on cut Chrysanthemum cultivars. Acta Hort. Sin 40: 1399-1406.

Huang MR and Qiang HL (1984). Rhododendron. China Forestry Publishing House.

Jha AB, Arganosa G, Tar'an B, Diederichsen A, et al. (2013). Characterization of 169 diverse pea germplasm accessions for agronomic performance, Mycosphaerella blight resistance and nutritional profile. Genet. Resour. Crop Evol. 60 : 747-761. http://dx.doi.org/10.1007/s10722-012-9871-1

Kumar S, Ambreen H, Murali TV, Bali S, et al. (2015). Assessment of genetic diversity and population structure in a global reference collection of 531 accessions of Carthamus tinctorius L. (safflower) using AFLP markers. Plant Mol. Biol. Report. 33: 1299-1313. http://dx.doi.org/10.1007/s11105-014-0828-8

Larsen B, Orabi J, Pedersen C and Orgaard M (2015). Large intraspecific genetic variation within the Saffron Crocus group (Crocus L., Series Crocus; Iridaceae). Plant Syst. Evol. 301: 425-437. http://dx.doi.org/10.1007/s00606-014-1083-z

Liu FL, Yao JT, Wang XL, Repnikova A, et al. (2012). Genetic diversity and structure within and between wild and cultivated Saccharina japonica (Laminariales, Phaeophyta) revealed by SSR markers. Aquaculture 358: 139-145. http://dx.doi.org/10.1016/j.aquaculture.2012.06.022

Miyashita T, Kunitake H, Yotsukura N and Hoshino Y (2015). Assessment of genetic relationships among cultivated and wild Rubus accessions using AFLP markers. Sci. Hortic. (Amsterdam) 193: 165-173. http://dx.doi.org/10.1016/j. scienta.2015.07.004

Mokhtari N, Rahimmalek M, Talebi M and Khorrami M (2013). Assessment of genetic diversity among and within Carthamus species using sequence-related amplified polymorphism (SRAP) markers. Plant Syst. Evol. 299: 12851294. http://dx.doi.org/10.1007/s00606-013-0796-8

Peng L, Ru M, Wang BQ, Wang Y, et al. (2014). Genetic diversity assessment of a germplasm collection of Salvia miltiorrhiza Bunge. based on morphology, ISSR and SRAP markers. Biochem. Syst. Ecol. 55: 84-92. http://dx.doi. org/10.1016/j.bse.2014.01.020

Pham TD, Geleta M, Bui TM, Bui TC, et al. (2011). Comparative analysis of genetic diversity of sesame (Sesamum indicum L.) from Vietnam and Cambodia using agro-morphological and molecular markers. Hereditas 148: 28-35. http://dx.doi.org/10.1111/j.1601-5223.2010.02196.x

Scariot V, De Keyser E, Handa T and De Riek J (2007a). Comparative study of the discriminating capacity and effectiveness of AFLP, STMS and EST markers in assessing genetic relationships among evergreen azaleas. Plant Breed. 126: 207-212. http://dx.doi.org/10.1111/j.1439-0523.2007.01326.x

Scariot V, Handa T and De Riek J (2007b). A contribution to the classification of evergreen azalea cultivars located in the Lake Maggiore area (Italy) by means of AFLP markers. Euphytica 158: 47-66. http://dx.doi.org/10.1007/s10681$\underline{007-9425-3}$

Souza LM, Mantello CC, Santos MO, Goncalves PD, et al. (2009). Microsatellites from rubber tree (Hevea brasiliensis) for genetic diversity analysis and cross-amplification in six Hevea wild species. Conserv. Genet. Resour. 1: 75-79. http://dx.doi.org/10.1007/s12686-009-9018-7

Valadez-Moctezuma E, Samah S and Luna-Paez A (2015). Genetic diversity of Opuntia spp. varieties assessed by classical marker tools (RAPD and ISSR). Plant Syst. Evol. 301: 737-747. http://dx.doi.org/10.1007/s00606-014-1112-y

Vos P, Hogers R, Bleeker M, Reijans M, et al. (1995). AFLP: a new technique for DNA fingerprinting. Nucleic Acids Res. 23: 4407-4414. http://dx.doi.org/10.1093/nar/23.21.4407

Wang S, Yin Y, Liu Y and Xu F (2012). Evaluation of genetic diversity among Chinese Pleurotus eryngii cultivars by combined RAPD/ISSR marker. Curr. Microbiol. 65: 424-431. http://dx.doi.org/10.1007/s00284-012-0177-5

Genetics and Molecular Research 15 (3): gmr.15038467 
Zhan MM, Cheng ZZ, Su GC, Wang AY, et al. (2015). Genetic relationships analysis of olive cultivars grown in China. Genet. Mol. Res. 14: 5958-5969. http://dx.doi.org/10.4238/2015.June.1.13

Zhang H, Ji WL, Li M and Zhou LY (2015). Genetic variation and genetic structure of the endangered species Sinowilsonia henryi Hemsi. (Hamamelidaceae) revealed by amplified fragment length polymorphism (AFLP) markers. Genet. Mol. Res. 14: 12340-12351.http://dx.doi.org/10.4238/2015.October.14.1

Zhao B, Yin ZF, Xu M and Wang QC (2012). AFLP analysis of genetic variation in wild populations of five Rhododendron species in Qinling Mountain in China. Biochem. Syst. Ecol. 45: 198-205. http://dx.doi.org/10.1016/j.bse.2012.07.033

Zhao B, Xu JJ and Zheng XZ (2015). Genetic relationship among nine Rhododendron species in Qinling Mountains, China using amplified fragment length polymorphism markers. Pak. J. Bot. 47: 1069-1074.

Zhou H, Liao J, Xia YP and Teng YW (2013). Determination of genetic relationships between evergreen azalea cultivars in China using AFLP markers. J. Zhejiang Univ. Sci. B 14: 299-308. http://dx.doi.org/10.1631/jzus.B1200094

Genetics and Molecular Research 15 (3): gmr.15038467 